\title{
Women Travel Writings: A Comparative Journey
}

\author{
Elmas Sahin \\ Department of Turkish Language and Literature, Çağ University, Mersin, Turkey \\ Email: elmassahin@yahoo.com
}

Received 2 December 2014; revised 18 December 2014; accepted 3 January 2015

Copyright (C) 2015 by author and Scientific Research Publishing Inc.

This work is licensed under the Creative Commons Attribution International License (CC BY). http://creativecommons.org/licenses/by/4.0/

(c) (i) Open Access

\section{Abstract}

Since the 18th century, Turkey increasingly played a significant role for women travel writers such as Lady Marry Montague, Elizabeth Craven, Julia Pardoe, Hester Donaldson Jenkins, Eliza Cheney Abbott Schneider, Mary Mills Patrick, Grace Ellison, who were in curiosity to discover the other: their cultures, customs, literatures, social, political and historical backgrounds and improvements, emancipation movements, sexualities and so on. Whereas some women writers including Zeyneb Hanım, Melek Hanım, Demetre Vaka and Halide Edib Adıvar penned impressions about both European and Turkey. In this study, the works named An Englishwoman in a Turkish Harem by Grace Ellison and A Turkish Woman's European Impressions by Zeynep Hanım will be evaluated in regard to comparative literature and cultural studies. Additionally, I argue that comparative literature accepted as a most advantageous approach for literary and cultural studies can probably contribute much more than the other disciplines to cultural studies and cultural history, even feminist cultural history, comparative cultural perspectives to literature; and or cultural studies open a large umbrella for international cultures and literatures in the light of these two works focused on literary writings, experiments, representations of occidental and oriental women, and occidental and oriental perceptions.

\section{Keywords}

Self \& Other, Oriental and Occidental Women, Comparative Literature, Cultural Studies

\section{Introduction}

Travel writing provides a large source, a huge way from "self" to "other" about perceptions, attitudes and quests of travel writers for the scholars interested in comparative literature, cultural or post-colonial studies. As in the historical progress of human being in all over the world, in the development of British and Turkish societies, 
women as activists, suffragettes or writers mainly had an important part for freedom, equal rights to men, and creations of new civilizations during $19^{\text {th }}$ century.

Many of the early female travel writers were either aristocrat, diplomat wives like Lady Marry Montague accompanying their husbands for the sake of business or diplomatic tasks, or housewives, suffragettes, journalists like Grace Ellison. However, by $19^{\text {th }}$ century most women travelers intending to discover strange lands and exotic countries as well as escaping from social and political pressures of their countries traveled with their own fortunes, and wrote their travel accounts in their books or several journals.

A Turkish Woman's European Impressions which consists of Zeynep Hanım's letters to Grace Ellison, an English feminist activist and journalist, the writer of the book called An Englishwoman in a Turkish Harem, is a book covered by cultural, social, political and literary comparisons of oriental women and occidental women by an "oriental" woman, Zeyneb Hanım. As for An Englishwoman in a Turkish Harem Ellison who is an "occidental" woman focuses on Ottoman women, male and female authors from last part $19^{\text {th }}$ century to the first part of $20^{\text {th }}$ century as well as some references to English women of her age.

Ellison's and Zeyneb Hanım's books as two significant works of women travel writing are rich sources for particularly emancipation history, culture, literature of both European and Ottoman Turkish woman, they extremely contribute to comparative cultural studies and comparative literature.

I argue in this study that these two works are the meeting points of comparative literature and feminist criticism, and/or comparative cultural perspective, comparative and feminist approaches. They can be described as comparative cultural studies as well as being comparative feminist criticisms of literature, which are a kind of engagement of comparative literature with feminist literary history and criticism. I also intend to compare Grace Ellison and Zeyneb Hanım's works, and to evaluate their orientalist and occidentalist approaches, comparisons in the works as examples of comparative cultural/area studies and comparative perspectives to the literature.

\section{Comparative Literature and Comparative Cultural Studies}

Before examining A Turkish Woman's European Impressions and An Englishwoman in a Turkish Harem, I believe that it will be useful to mention comparative literature as a discipline meaning study of a work/literature to the other(s), embracing any study of literature beyond the national boundaries. While Edward Said in his Culture and Imperialism describes comparative literature as a field "whose origin and purpose is to move beyond insularity and provincialism and to see several cultures and literatures together” [1]; Tötösy de Zepetnek defends "comparative literature has an ideology of inclusion of the other, be that a marginal literature in its several meanings of marginality, a genre, various text types, etc.," [2].

The fact that comparative literature is "to speak of the interaction of world literatures with one another" [3], or "the recognition of and the engagement with the other" [4]; has been supported by most of the corporatists for many years. Comparative literature, as an approach to compare literary works of different nations behind the boundaries, to study one's impacts on the other means the knowledge of more than one national language and literature, as in [2]. Therefore we can intermingle or merge comparative literature with the words international, multicultural or cross-cultural or “comparative cultural studies”[5] as Tötösy de Zepetnek suggests.

After Susan Bassnett declared "comparative literature in one sense is dead" [6], nowadays the discipline of comparative literature as even manifesto of a new comparative literature has strongly been going on developing. In the words of Spivak, "Cultural Studies and Ethnic Studies are on the rise" [7]; however, comparative literature also is still popular in terms of multiculturalism interdisciplinary, that is hand in hand with comparative cultural studies [8] as Roland Green addresses similar things for comparative literature in the multicultural age [9] as well.

Based on all these views, it will be possible to say that comparative literature produces meaningful dialogues between cultures and literatures, knowledge of self and other as seen in Ellison and Zeyneb Hanım's works. Relationships and dialogues between cultures, literatures, languages, histories, periods, or disciplines by their similarities and dissimilarities are translated, transformed from one culture into another by comparative approaches. When thought in terms of literary and cultural values, "the comparative study of texts rests on assumptions about the group identities not only of authors but also of texts” [10].

Curiosity of learning the other beyond boundaries from perspective of a new comparative literature at our age will bring to light the national or local ones thanks to comparative/cultural studies to literature. In other words, one who knows her/his own literature closely will strongly do comparisons about self and the other; it will con- 
tribute to the world literature as "a discipline paid more attention to "Other" literatures than any of the national literatures" [2]. Shortly "the comparative study of Literature not only opens an immense field of fruitful labour but tends to foster creative imagination" [11].

In this study, when evaluated two female writers" works as multi-dimensional texts for comparative cultural and feminist studies and comparative literature, Ellison's An Englishwoman in Turkish Harem (1915) is observed as the story of a journey, an admiration into the heart/land of the "other," as exotic comparisons of the East and the West. On the other hand Zeyneb Hanım's letters in Turkish Woman's European Impressions written between 1906 and 1912 (including two letters by Melek Hanım), which were sent from several countries of Europe to Ellison are built on her own quests, impressions and prejudices of the Occident and Orient, and details of her oriental life in Ottoman period at the beginnings of the $20^{\text {th }}$ century. Zeyneb Hanım's book published in London in 1913, edited by Grace Ellison are illustrated with oriental and occidental photographs of Ellison and Zeyneb.

In the following part, the travel book of Ellison trying to break stereo-types orientalist discourses during her life in Turkey, finding some opportunities to re-examine women's position and literary and cultural developments in Europe is compared and contrasted by Zeyneb Hanım's impressions in Europe, particularly in England and France.

\section{A Comparative Journey: Curiosity and Prejudice}

The epigraph "what is to be compared with what, by whom, to what end, and under what conditions" [12] uttered by Gloria Anzaldia to the comparatists or readers $(1987,195)$, will also be a significative guide for framework of this study.

Here, I try to focus on how Grace Ellison and Zeyneb Hanım construct their travel accounts and narrate places they have visited and seen, their relations or conversations with the others, and writers they have met; shortly, an Englishwoman's curiosities and admirations of the other to a Turkish woman's prejudices and disappointments of self from a perspective of feminist comparative literature are reflected by a new standpoint as a contribute to not only literary criticism and cultural studies, but also comparative literature through the works.

From the $18^{\text {th }}$ century to the present day, not only male writers but female travel writers are increasingly tended to write "other" in travel writings. Grace Ellison and Zeyneb Hanım like Lady Mary Montague focused on differences of native women of the countries they traveled, and compared and contrasted foreign women to their societies" women. While Grace Ellison paid attention to positions of oriental women of Ottoman period from last part $19^{\text {th }}$ century to first part of $20^{\text {th }}$ century culturally, literary, socio-politically, she reported on her self-attitudes, as well as on her attitudes towards the other, Zeyneb Hanım had a tendency on occidental women of England and France and the other European countries.

Grace Ellison as a friend and admirer of the Turks, and student of their language and literature for nearly forty years had a chance of comparison between Turkish and European culture, literature, language, customs, social, political, economic and oriental harem life. But Ellison observed Ottoman Turkish women much more objectively than the other European writers who had long looked East by orientalist points of view; the other side, Zeyneb Hanım did similar impressions for the West and her own homeland.

The travels to East and West were depicted mostly, as "Travel is sacred. Travel is a quest. Travel is an escape" [13] in Ellison and Zeyneb Hanım's works. In fact, Zeyneb Hanım's fascination to the West she supposed as "land of freedom" began with a biographic novel told her and her sister Melek Hanım's life-Les Désenchantés/The Disenchanted — built in a collaboration by the French author Pierre Loti.

These two sisters, Zeyneb (her real name Hatice Zennur), Melek (Neyr) who used these pseudonyms as characters of Les Désenchantés were lovers of freedom. They were treated by a Western-style education, whose grandfather was Marquise Blosset de Chateauneuf who was a French nobleman, a military officer in the service of Sultan Abdülaziz, were the daughters of Nuri Bey, Minister of Foreign Affairs in the period of Sultan Abdulhamit II. Their grandfather French Chateauneuf became a Turk, embraced Islam, and married an Ottoman woman, then took the name Reşid (Rechid) Bey [14].

Before printing of Les Désenchantés, the sisters had escaped from Istanbul in 1906 for fear of imperial and social attacks and their restricted lives in Istanbul. They hoped happiness and peace; yet they would disappoint with statues of Western women that they observed closely, the letters sent to Ellison in the book of Zeyneb Hanım would reveal realities of beginnings of the $20^{\text {th }}$ century. Europe was not Europe that she thought while 
she was in her home. Her curiosity, admiration and prejudices to the other's in the quest her travels through the Western countries like France, England, Spain and Italy would comparatively turn into occidentalist criticisms in her Turkish Woman's European Impressions.

\subsection{Women's Emancipation}

By the $20^{\text {th }}$ century, social and political emancipation of Western women were not so much different from Eastern women. Perhaps the only difference, while the Western women almost were struggling alone for their rights, Ottoman men struggled more than women for women's emancipation did. "In contrast to the negative treatment of suffragists in England, ranging from rudeness to brutality, Ottoman women had the advantage of substantial and active male support" [15].

Ottoman Turkish women are compared to British ones (p. 65) in the book of Ellison closely knowing emancipation movements in Britain; she surprises when she witnessed "men's supports and encouragements to women. Conversely Zeyneb Hanım who has a chance to know Englishwomen in London cannot fully realize demands and way of straggles of suffragettes in the street meetings, women of the other civilizations seeking freedom socially or politically. Zeyneb Hanım in inactive nature of Turkish woman having quite character cannot perceive mood of English woman crying on the streets. She describes English suffragists as "undiplomatic, brutally sincere" [16]. The most significant aspect between them is that their fighting styles for freedom are dissimilar; both Ellison and Zeyneb will undermine and compare their similarities and dissimilarities through the works.

As if Zeyneb Hanım took a small flight around the universe to see women of the world as the Fur Free Fox did, reminds us the story of "Shop the Fox" and shop with her return from the journey her homeland. "She is back in her little Yali again.” That is, nothing ended, as she desired before leaving her country, her hopes are destroyed, nothing is, as it seems. Europe is a paradise from far away, but it is not any different from Eastern harem when observed closely. Was the thing that Ellison describes as "wonderful liberty of the West," very ugly humiliation of suffragists in London streets where Zeyneb Hanım met? "A class of man I had not yet seen. All the time they interrupted her, but she went bravely on, returning their rudeness with sarcasm. What an insult to womanhood it seemed to me, to have to bandy words with this vulgar mob. One man told her that "she was ugly" (p. 190) Zeyneb emphasizes her feelings in this way in her book.

Ellison also shares this kind of idea "England is never for them the England they (Turks) had dreamt of and wished to see" (p. 72). While Zeyneb Hanım lives a great shockwave against English suffragettes crying for "vote;" philosophical and scientific words of a feminist male speaker explaining to women the value of their sexes have a very deep impression on Ellison who asks ““'Am I really in Turkey?” I frequently asked myself...I wonder, in my country a feminist meeting conducted only by men and where the men urged the women to rebel and strike for freedom?” (p. 71).

As Grace Ellison recognizes in Istanbul, Ottoman women are silent except a few of them against impositions of ottoman government are willing women's liberation role is largely undertaken by men. When observed by Zeyneb Hanım's points of view, if Englishwomen have no desire or no effort to enjoy from the life or for her equal rights to men, if it is true, then this situation is valid Ottoman women as well. Even Ellison learns that the men have even written articles for the newly founded woman's paper, and signed them with feminine names, that the number of women writers here is still very limited (p. 65).

In her book, Ellison observes that Turkish language except uneducated people or members of the new nationalist movement was neglected in the elite of Ottoman mostly having spoken French. In fact, this situation was not different from England of $11^{\text {th }}$ and $12^{\text {th }}$ centuries; English was also under effect of French result of Norman Invasion in 1066. Yet English began to change slightly from 1204 to 1453. English was spoken in villages or lower classes, was negatively under affection of a strange language. It is very strange that Ellison does not mention about this.

\subsection{Literary Attitudes}

Ellison is extremely interested to Turkish writers of $18^{\text {th }}$ and $9^{\text {th }}$ century. She expresses her admirations about Halide Edib Adivar as both feminist and nationalist woman writer, as the most talented of Turkish writers (p. 66). Halide Edib's strong voice and straggles are close to Ellison, she is like suffragists in her country. On the other hand, Grace Ellison introduces and makes comparisons between Turks and Persians, their literary skills 
and poetic talents of Turkish male writers like Şinasi, Ziya Pasha, Namık Kemal, Abdülhak Hamit Tarhan; the female poets and writers like Leyla Hanım, Fitnat, Mihri Hatun, Nigar Hanım, Fatima Aliye Hanım, Emine Semiye Hanım and Halide Edib. She is influenced by Halide Edib's novel Handan, or Udi (The Lute Player) by Fatma Aliye Hanım and by Nigar Hanım's beautiful lyrics into from Turkish to French and German and so widely (pp. 107-109).

Ellison compares Udi's original and French translation. The comparisons from insufficient translations will not be trustful and will not give the same taste with its original. This also is to approach to comparative literature in terms of language. "Comparative literature implies that between two related languages there are areas of significance that are shared, just as there may be areas of significance that can never be shared" [17]. Thus, Translation is noticed as aesthetic problem rather than a linguistic one in Ellison's comparative perspective. Grace Ellison also gives information about translations of French classics into Turkish as well as writers of the age like Şinasi, Namık Kemal but so much French impressions on Turkish literature surprise her, the sale of French books in Turkey is enormous. Nevertheless, English is limited.

As Bassnett says, as a result of interactions between literatures behind the boundaries, "translation can serve as a force for literary renewal and innovation, translation has played a vital role in literary history through translation come new ideas, new genres and new forms” [18] just like French impression on Turkish literature. Naturally, this interest in French writers will be compared, and an English woman writer will question her own country.

Ellison claims that the "spirit of English literature" (p. 117) is much better suited to the Turkish character with comparative cultural approach. "In appearance, too, Turkish men are so like Englishmen. She is in thought that this neglect of English literature is very largely their own fault, Grace Ellison is a cultural representative, for introducing of British culture and British literature in Turkey, and she cannot help asking the reasons of this in a colonialist way. "What have we done to spread the knowledge of our language in the near East? And what has France done? Les Dames de Sion, the Lazarists, and the innumerable other orders... And we?!” (p. 118)

Turkish readers who read English classics are limited; one of them is Zeyneb Hanım who is a Turkish woman reading a great deal of foreign literature, but remarking with the words "this does not tend to make us any more satisfied with our lot. Amongst my favorite English books were English suffragette Beatrice Harraden's Ships that Pass in the Night, passages of which I know by heart, and Lady Mary Montagu's Letters” (p. 38) Impression of Harraden's novel on Zeyneb in European journey is clearly recognized as if Zeyneb's journey is a journey of Londoner Bernardine's inner life staying in Hotel Petershof which is a winter resort for consumptive patients in Switzerland because of her illness. Just as the heroine of Beatrice Harraden.

In a letter that she wrote to Ellison from Caux on January of 1907 Zeyneb Hanım emphasizes, "the articles which I have written for you on the beauties of Switzerland will possibly not appeal to the British public" (p. 107). This British lady most likely can be Bernardine dying at the end of the novel in her memory. She compares Bosphorus of Istanbul for its resemblance to Leman, "Leman for helping you to understand how wonderful is the Bosphorus. But the poetry of moonlight does not appeal evidently to the British soul” (p. 108).

Grace Ellison and Zeyneb Hanım's literary dialogues between the Turkish and European authors and ideas about foreign literatures have very great importance from comparative perspective to literatures of the East and the West. Both female writers incompletely or completely close Orient to Occident or Occident to Orient, build a kind of bridge behind the boundaries, between cultures and literature, of course the reader will fill in the blanks.

While Ellison to Turkish writers like Halide Edib and Fatma Aliye has a talk on social, political and cultural issues, Zeynep Hanım also does similar things. After her arrival to Nice, to France she visits the cemetery of Birreyatou together with Pierre Loti, but instead of her literary talks she concentrates on the cemetery, and compares a Western cemetery to Turkish one. Its likeness to Turkey attracts her at once. Even she offers Ellison to visit Turkish cemeteries to compare with the ones in her own country. However, it is important her to visit Musset's tomb in Pere La Chaise, to steal a leaf from the famous weeping willow on Musset's grave. Yet his grave becomes a great disappointment for her. "How you Western people neglect your dead!” (p. 160)

Zeyneb does not speak a lot about Loti, but she visits Empress Eugénie, the Second French Empire, and she narrates the disastrous influence of Eugénie on Turkish fashion and culture, and her visit to the East, and Ottoman lands of Abdul Aziz's period, she expresses her feelings in a large way about Eugénie. She is "the Empress whose beauty fascinated the East, the Empress whose clothes the women copied, whose language they learnt, the woman who had...the greatest influence on the lives of Turkish women” (p. 133). The Empress, who re- 
membered with great pleasure every detail of her visit to the East, asks questions full of wonder to Zeyneb, in fact most of them are orientalist interests, curiosities to the other. "Are the women still as much veiled as when I was in Constantinople ?” (p. 135) asks the Empress.

One of the English aristocrat and travel writers concerning Zeyneb Hanım is Lady Marry Montagu. Her Turkish Embassy Letters she reads with fresh interest are remembered as Montagu's charming and clever letters. Her agreements with the Montagu's letters and thoughts smelling orientalism are very surprising. Describing Ottoman as a country "where the number of faithful wives are very small and where (these married women) they have nothing to fear from a lover's indiscretion" [19] Montague's orientalist descriptions on Turkish women escape from Zeyneb's attention. She is very far from understanding Lady Montagu while Zeyneb says, "there is nothing in them to shock or surprise a Turkish woman of to-day in their criticism of our life. It is curious to notice, when reading Lady Mary's Letters, how little the Turkey of to-day differs from the Turkey of her time ; only, Turkey, the child that Lady Mary knew, has grown into a big person” (p. 38).

When Zeyneb Hanım was in London, she had chances to see performances of plays and musicals. For instance she goes to see performance of Sir Herbert Beerbohm Tree as Svengali in "Trilby" by Thomas Charles Turner at His Majesty's Theatre has a delightful dinner with Sir Herbert Tree (p. 196); and she watches the Englishwoman, actress Miss Ellen Terry in the scene, her act will be comforting for her (p. 198).

\subsection{Englishwomen and Turkish Women: Satisfactions and Dissatisfactions}

While Ellison is mostly interested in "harem and Turkish women," Zeyneb in a quest of freedom is concerned with the "Houses of London Parliament." But she will meet a bad Parliament experiment and she will be faced with many disappointments. Zeyneb expresses her feelings before her visiting the Parliament in these words: "I was very anxious to see the notorious Mr. Lloyd George. Since I have been in London his name is on everyone's lips” (pp. 194-195), Zeyneb invited to a tea party by her friend, a Member of Parliament to House of Commons has a chance to compare atmosphere "free” England to Hamidian regime of Ottoman. Ladies" Gallery looks like an oriental Harem in imagination of Zeyneb Hanım, and the harem-like atmosphere she described astonishes her; and she asks Ellison its meaning. "Why have you never told me that the Ladies" Gallery is a harem? A harem with its latticed windows! The harem of the Government!... Is it in Free England that you dare to have a harem?" (p. 194).

Despite of everything her impressions of European women throughout her travels are full of disappointments. Zeyneb Hanım who observes women in Ladies" Club in London as well as women in the countries she traveled dislikes an unfamiliar landscape of this club like the PM so much, everything almost reminds of Harem in Istanbul. In no way, she cannot find "free" woman in her imagination. Her feelings are uttered to an Englishwoman in the club by satiric sentences "like Diogenes who tried to find a Man, I have been trying to find a Free woman, but have not been successful” (p. 200).

Zeyneb feels herself like a désenchantée, she is hopeless, she also thinks that Ellison is hopeless, and she compares characters of two nations. As if London and Istanbul were covered by spleen of Paris. The only difference between the spleen of London and the spleen of Constantinople is that "the foundation of the Turkish character is dry cynicism, whilst the Englishman's is inane doggedness without object. In his fatalism, the Turk is a philosopher. Your Englishman calls himself a man of action, but he is a mere empiric” (p. 203).

Grace Ellison openly tries to question representations of the West and the East by few sentences in a sense of democracy and monarchy, how the British Government or Turkish one treats its women. "An action committed by a Turk should be called "a crime," and yet committed by a Christian neighbor "a diplomatic error" (p. 80). These two women also say similar things in fact they satirize both their own society, and the other's, sometimes they are orientalists, sometimes occidentalists. Grace Ellison compares Turkish and English governments with partly ironic expressions: "The Turkish Government has been wiser than we in this matter, for it recognizes that education and the housing of the poor are questions which should be left as much as possible in the women's hands. A Turkish Feminist Government! To Western Europe this sounds strange” (p. 81).

Grace Ellison evaluates Turkish women and European women from literary and comparative cultural perspectives. The Turkish woman is described by a modesty leading her into a lack of self-confidence, is "unlike the women of Western Europe, she has not inherited the tired brain of tired ancestors; she has now awakened after centuries of rest, with a brain fresh and ready for work" (p. 106).

Ellison's An Englishwoman in a Turkish Harem from beginning to the end is full of impressions, interpreta- 
tions and experiences of Ottoman Turkey as well as comparisons of manners and customs of Orient and Occident. The first section of A Turkish Woman's European Impressions by Zeyneb Hanım is focused on the reasons for she and her sister Melek's escapes from their homeland to Europe for liberty, and the other chapters are divided into comparisons between Occident and Orient. In almost her every letter, she compares Turkish women with Western ones through her travel in Europe. Zeyneb draws attention European's curiosity sides about their flight after printing of Pierre Loti's novel. "All the European papers have judged us impartially, some have even defended and praised us, but not one censured us for doing with our lives what it pleased us” (p. 25); and she adds, "Do you know, I begin to regret that I ever came in contact with your Western education and culture! But if I begin writing of Western culture, this letter will not be finished for weeks" (p. 78). When she was in Turkey her first impressions of Europe partly are positive, but after her escaping enormous changes begin in her ideas in opposite direction.

From time to time Ellison who praises and satires both Eastern and Western women like Zeyneb, behaves like an English attaché with her nationalist side of Englishness and evaluates Zeyneb’s disappointments in London in an occidental superiority. "I had not seen her since she so resolutely and forever closed the book of her European experiences, and our first meeting was just a little painful. Zeyneb is a dear friend-a curious, interesting study - a woman who had gone forth with a flourish of trumpets to try the great, wonderful liberty of the West, woman who cast aside her own civilization to throw herself before the altar of ours. She was not prepared for our civilization, she was not armed for the fray, the hurricane of progress took her off her feet, and now... she is back in the little Yali again (p. 187).

\subsection{Veil and Hat}

One another issue in center of attraction is of "veil and hat," which are compared by Ellison and Zeyneb Hanım. Impressions on veil and hat of Turkish and European women become a comparison subject. Ellison will wear a veil, Zeyneb will a hat. Their roles will change, Ellison as a Turkish lady is replaced with Zeyneb. Zeyneb is in London, the other is in Istanbul. They will observe and try to understand the worlds of each other. Both of them will handle veil and hat issues comparatively as aesthetic objects to their literary works.

When studied their perceptions of veil from comparative points of view, it is recognized that veil means a veil between her and the sun, a veil to prevent her from seeing the sun for Zeyneb. But Ellsion knows what it means for suffragette Turkish woman "it is the darkness before the dawn" (p. 32), but a veil for Ellison is a tool for her to establish close relationships with Turkish women, to look lovely, pleasant or cute to the eyes of Turks. Zeyneb says in a letter dated 15 Feb. 1907 to Ellison from Nice "you cannot know how this simple black veil, which covers our faces, can completely change the whole conditions of the life of a nation” (p. 119).

Very interestingly, Ellison wears veil and Turkish clothes like a Turk. She lives in Turkey instead of her own country that she saw as "the country of liberty," while England has "a wonderful liberty." Why does she prefer Ottoman Turkey? What is her business in the Orient? What is her goal? Is this a necessary task for her journal? Or is it an orientalist curiosity? Or does she have a mission as a cultural attaché ? Certainly my aim is not to criticize or blame Ellison, of course she is such a Turkophile, more different, as a feminist journalist, and a writer drawing attention to good and bad everything, more objectively than the other orientalist travel writers of the Occident, even confessing the biased approaches against Turks.

Ellison admits orientalist accusations and injustice attitudes of the West against Turks: "We have been unjust to Turkey; we have for so long confounded the Turkish subjects with the cruel despots of the Hamidian regime; we have for so long now condemned wholesale everything Turkish, and the novel-writers of the day describe a Turkey which certainly does not exist to-day" (p. 55). Such a writer from country of the "liberty" to the country of "bondage" comes and she wears veil, lives in an Ottoman Harem as a free, liberal European woman, this is very surprising.

Ellison partly gives an answer of this attitude. "Dear Old Hadgi, she could be such a sweet angel. She tied me up with charms to protect me from the evil eye, she sang to me and admired me and loved me, but only as long as I was veiled when I wore a hat I was a stranger to her-not one of the "faithful" (p. 184). But is everyone like Hadgi? This can be questioned. This can be true for a way of Hadgi's perception self and the other; nevertheless, that Ellison behaves as if she is a Turk is a kind of trick. It seems to me like a way of knowing better and closer Turks or Orientals.

Even Ellison acts "as a Turk," not like a Turk. "AND now the time has come for me to return to my native 
land, I ask myself what have been my final impressions of my life "as a Turkish woman” (p. 195). Such that, she accepts this cultural mission in order to introduce English language, literature, culture and civilization to Turks consciously or unconsciously. And she "closes the diary of her existence as a Turkish woman" (p. 200). That is, her task is finished in Turkey "as a Turkish woman." In Turkey, she is a Turk, but she is an Englishwoman in England. "And so here I am in the heart of Stamboul, a Turkish woman for the time being” (p. 17). However, when time comes, she will return to her hometown. At least Ellison in her work tried to open a window to the real characters of Eastern men and women, attempted to correct errors, prejudice and hatred towards Turks about harem misunderstood or misjudged, polygamy, culture, literature or traditions and customs.

Ellison also brings different comments on subjects of women and veil "to ask a Turkish woman to go out without her veil is almost like asking an Englishwoman to go out without a blouse" (p. 76). This thought is questioned by Ternar "a Turkish woman's face is an Englishwoman's breast. Can we say then that a Turkish woman's face is just as sensuous as an Englishwoman's breasts? Or that a Turkish woman carries her heart behind her face and therefore needs to protect it?" [20].

Of course there are various different usages of veil by woman as symbol of religious beliefs, culture, protection, habit, spirituality, suppression or submissive. However, if a woman wears it freely because of her own beliefs, a customary tool, or habit instead of religious forces; that woman will perhaps feel naked in front of the society, in fact, what Ellison wants to express clearly is this. Shortly a veil symbolizes "bondage", an "oriental woman" from western points of view, but a hat symbolizes "freedom" a modern occidental woman in eastern women's eyes.

\subsection{Similarities and Dissimilarities: Self and Other}

As for characteristics of oriental and occidental women in the works, Ellison and Zeyneb Hanım compare and contrast English and Turkish women by various perspectives. Throughout the works, several representations of East and West are comparatively given by both writers. One of the most interesting ones is hidden in Zeyneb Hanım's question "what is there in common between you and us?" (p. 119) posed to Ellison. These sorts of questions are valid for comparative literature focused similarities and differences, interactions, relations between texts as well. Comparative cultural approaches to the West and East largely draw attention as the common features of Ellison and Zeyneb Hanım's works. The question of Zeyneb Hanım's "What is there in common between you and us?" opens a huge window to the self and the other. "The heart," you will say. But is the heart the same in the East as in the West? And what a difference there is between our methods of seeing things, even of great importance. Ambition with us does not seek the same ends; pride with us is wounded by such a different class of actions; and individuality in the East seeks other gratifications than it does in the West” (p. 119).

Once again, such a question is uttered by another Turkish woman to Ellison. Perhaps Zeyneb Hanım is right; the answer is "heart" that Ellison confirms silently (p. 99). Neither the Orient nor Occident sometimes succeeds in understanding feelings of each other, or says anything, tries to feel if they achieve. Ellison transmits her feelings in this way: "We, Westerners, with our curious ideas of Eastern life, cannot imagine the picturesque, simple, and natural attitude the Turks have towards death. None of the hideous wailing, the rending of garments, sackcloth and ashes (supposed to be part of the Eastern mourning); none of our Western terrifying preparation for the long last journey; no mourning, no flowers, no funeral cards; it is as if the dear one had gone on a journey to a foreign land, and his family and friends pray for him as if he were still alive” (p. 50).

Zeyneb Hanım's travel account in Europe highlights the similarities between East and West, she recognizes limitations of harem in both Orient and the Occident, therefore she cannot be happy completely, and neither London, nor Paris, and the other European cities are satisfactorily. Shortly London of England is not so much different from Istanbul of Turkey, nor better than the other is. For Zeyneb "the Englishmen remind her of the Turks. They have the same grave demeanour, the same appearance of indifference to our sex, the same look of stubborn determination, and, like the Turk, every Englishman is a Sultan in his own house. Like the Turk, too, he is sincere and faithful in his friendships, but Englishmen have two qualities that the Turks do not possess. They are extremely good business men, and in social relations are extremely prudent, although it is difficult to say where prudence ends and hypocrisy begins” (p. 214).

In addition, Zeyneb says more: "But if Englishmen remind me of Turks, I can find nothing in common between English and Turkish women. They are in direct contrast to one another in everything.... A Turkish woman's life is as mysterious as an Englishwoman's life is an open book, which all can read who care... English- 
women are pretty, but are deficient in charm. They have no particular desire and make no effort to please. You know the charm of the Turkish woman. The Englishwoman is pig-headed, undiplomatic, brutally sincere, but a good and faithful friend.” (p. 215)

What about the Turkish people? Ellison will fill that in herself, describe Turkish women as "more pureminded, perhaps, than the women of any other nation" (p. 108). Even so, Grace Ellison emphasizes, "the Turkish woman is proud, and insists that her dignity be respected, and, personally, I know few who would put up with the polygamy which women of the Latin races are obliged to accept. When a Turkish woman marries, her/ husband is obliged according to his means to make a settlement; this sum becomes hers should she find it necessary to divorce him. So, when a wife has cause for complaint, she claims her dowry and personal effects, and returns to her family or nearest relative, and both husband and wife are free to marry again” (p. 58).

Some warm and friendly hospitality in most Turkish houses surprises Ellison accustoming to hearing insulting opinions. "It is the custom, too, for the master of the house to pay all the visitor's bills. That I should have proposed to stamp, my own letters hurt my friend. The result is that, nowadays, I write no letters and buy practically nothing. I feel almost guilty when I accept what I do and give nothing in return, and always I have before me the haunting fear of the terrible disappointment my friend will have when she visits my country, for our hospitality cannot be compared to this" (p. 22).

Ellison does not keep quiet and goes on sharing her feelings about real sides of the hearsays on Turks or false evaluations of many orientalist writers. She explains impressions of Turkey in these sentences: "The more I stay in Turkey the more I admire the inborn aristocracy of the Turk, and yet "aristocracy" as we understand it does not exist. Turkey is the country where brotherhood and equality have been best understood. The Turkish woman does not often open the doors of her home to the foreigner, not for lack of any friendly feeling towards her, but because the foreigner has lost her confidence, the foreigner has made fun of her and, above all, the foreigner "pities” her. But when the Turkish woman opens her door to the foreigner, she opens her big, generous heart” (pp. 21-22).

On the other hand, Grace Ellison criticizes and clarifies the wrong perception of the harem by most of orientalist considering "the women as beautiful, idle and intriguing creatures and 'passion' as the only drama that is played within its mysterious walls" (p. 108). At the beginnings of her work, "now I understand that lack of what we English call "common courtesy.” We have misjudged the Turks. A pen in the harem!” (p. 4) Ellison confesses in one sense. Despite of her criticisms about some harem-like limitations of London reminding of harem and her horrors at humiliation of feminists before public on the street meeting Zeyneb also thinks that she finds true peace and security in England. "What a magnificent city London is! If you English are not proud of it, you ought to be... Here in London I have a feeling of security, which I have had nowhere else in the world” (p. 212).

Both Ellison and Zeyneb bring extensive comments to every side of life in terms of social, political, cultural, religious or literary values the Orient and the Occident. The "other" always is attractive to woman satisfied or dissatisfied with her own "self." The other or the self is curiosity in seeking freedom or adventure or the secret of what is important in life of one another. For example at the end of her quest everything is more or less the same for Zeyneb, fascination and frustration are mingled to each other. When she compares her country to the other's, she recognizes the democracy of the East is so different from that of the West, as so pitiful examples at the street corner or her invitation to tea at the House of Commons seem very strange to her. Moreover, she and Ellison cannot help comparing Turkish and English culture about matters of habits.

While Zeyneb understands clearly the drinking of tea is such vital important that the English can never do without it. She wonders "if the Turks, now their Parliament is opened, will drink coffee with ladies instead of attending to the laws of the nation!” (p. 191) Ellison observes every time coffee is served, and coffee is offered to every visitor. "I take a cup; it gives me a better chance of studying the curious scene in which I am playing a part, and the more I look, the more beautiful it seems to me, and it makes me almost sad to think I cannot meet this spirit of democracy In any other land. (p. 54)

In her another letter dated Nov-Dec. 1908 from London Zeyneb complains about fogs of London where she cannot be accustomed to just its unfamiliar space, however Ellison enjoys sunny weather of Bursa or Istanbul. "Whilst you were writing your first letter to me and speaking of the beautiful Eastern sun that was shining through your latticed window, what a different experience was mine in London. I was walking by myself in the West End, when suddenly; the whole city was shrouded in one of those dense fogs to which you no doubt have become accustomed" (p. 181). Some aesthetic pleasure Ellison has is described in an enviable beauty as a comparison of two cities. "When I think of London at this moment, shrouded in fog, whilst we are surrounded by a 
blue sky, a blue sea, trees in all their autumn glory, and the air which caresses my face like iced velvety I am thankful for what Broussa can give me at present” (p. 141).

English women in a Ladies” club are described as stereo-type characters by Zeyneb Hanım. She finds the club is indifference from all another kind of harem. She feels a deserted peace among people who spoke in whispers, wrote letters, and read the daily papers. Zeyneb associates the atmosphere of the Club with isolated liberty. "The silence of the room was restful, there was an atmosphere almost of peace... but it is the peace of apathy. Is this, then, what the Turkish women dream of becoming one day? Is this their ideal of independence and liberty?” (p. 185).

As if spirits of these two works were the mirage of the East to the mirage of the West (p. 186) according to Zeyneb, in Zeyneb's eyes, Englishwomen seem satisfied by their "liberty" in the "isolated room." Yet in the words of Ellison they are not more different than the Ottoman "women who declared themselves perfectly satisfied with their "bondage", and yet at the same time worked in secret to break those chains, have now come out in the manner of the Western women, openly to demand their rights (p. 80).

In one aspect, Grace and Zeyneb's travels are mental ones as well as physical journeys. In a letter reflecting her long inner life from Swiss Alps, from Territet, on December of 1906, Zeyneb puts the last point. The life seems very strange and unpleasant for her mood (p. 65) that she stayed more than a month with people of all ages in incredible interest to shores of Lake Leman.

\section{Conclusions}

While Zeyneb Hanım travels to escape from gender oppression in Abdulhamit period, the travel to the East by Ellison begins with personal curiosities of exotic lands, collecting data and seeking travel accounts for her journal.

Both of them deal with matters like superiority or inferiority, subordination or insubordinations, advantages or disadvantages of various characteristics of Eastern and Western women as well as cultures, customs and literatures of The East and The West. Their works are rich sources for woman or feminist history of "self and other".

Grace Ellison dresses in Ottoman clothes for several reasons: to satisfy her curiosity, to observe the oriental Turkish women closely. She enjoys the aesthetic pleasure from focusing on gender analyses of the oriental literature and culture, customs and beauties of Eastern women. Thus, she has a chance to know both the "other" of the East and her "self" of the West and she realizes similarities and differences between the Orient and the Occident. As if she assimilates herself to a Turkish woman by wearing Turkish coats and trousers, even veils. She appears as if she occasionally criticizes European women while she mostly praises Turkish women. She is a typical Victorian woman compared her self-reliance to "other," an occidental Turkophile supporting struggles of oriental women under the Hamidian regime.

As for Zeyneb Hanım, she is an oriental feminist woman seeking freedom by escaping from bandage, oriental solitude an educated woman of ottoman elite questioning her "self" and the "other." She is a quest. She also criticizes and praises Ottoman women as much as European ones, especially she has good impressions about Western women before leaving from Istanbul, yet the days in Europe are full of disappointments. As if Ellison's female accounts, individual experiences, arguments, dialogues, admirations and representations of Orient and Occident are answers to Zeyneb Hanım's letters. Their West/East divisions are reflected from several windows. Both of them will return their home at the end hopelessly or hopefully. While Zeyneb's sister Melek Hanım married a Polish aristocrat, and lived in Europe, Zeyneb came back her homeland.

Zeyneb Hanım escaping together with her sister Melek from Hamidian regime cannot find freedom she hopes, or whatever she seeks is nothing more than frustration, her long of quest from 1906 to 1913 as journey of "a curious harem! And what a difference from the one in which you are living at present” (p. 182) is a disappointment to her rather than pleasure. Yet to some extent Ellison finds what she looks for, she has a chance to know or observe the "other" in oriental houses or harem in the words of Western orientalists. Well is she happy? Maybe as a cultural attaché succeeding her task well, but I think a feminist woman is not. Her "free" England is not as she hopes, she also has complaints about both the West and the East as we examine above Ellison and Zeyneb's comparisons of Orient/Occident or divisions are noticeable clearly.

Commenting European impressions of Zeyneb and her sister Melek, Reina Lewis claims "the sisters were unable to recognize the signs of Western freedom as truly valuable: they could not get over the pointlessness of sport or the crazy pace of a Paris Season. They looked with eyes that were both haremised and haremising, 
finding the harem in Europe” [21]. This idea can partly be true for Zeyneb becoming unfamiliar to different cultures, getting used to be her culture and customs, having a fright from feminist street demonstrations of London, living under pressures of Ottoman imperial regime; but for not Melek who married and settled in Europe. Because Zeyneb Hanım seeks peace, a "noiseless" freedom, activities, cries of suffragists in the streets can be frightened her. Her impressions reflecting comparatively in the center of West/East from top to bottom in her book indicate reasons of her disappointments, unsatisfied mood.

Thus, Grace Ellison's An Englishwoman in a Turkish Harem and Zeynep Hanım's A Turkish Woman's European Impressions are valuable as texts of a "new comparative literature" contributing cultural studies or comparative cultural studies as well. Comparative literature which is the study of literature beyond the borders of one particular country, and the study of the relationships between literary texts, is interested in "other." It focuses on relationships between self and other, including literature, fine arts, or, philosophy, history, sociology, in Remak's words “theory, the sociology of literature (including Trivial literature), linguistics, rhetoric and the interdisciplinary study of literature” [22], and so on is the comparison of one literature with another or others, and the comparison of literatures beyond borders.

Comparative literature as "the comparison of one literature with another or others, and the comparison of literature with other spheres of human expression [23] finds its meaning in terms of comparative/cultural feminist studies in the works of Ellison and Zeyneb in feminine writing. Their approaches are studies of historical periods, texts, themes, genres, translation, movements (women's movements and suffragist/feminist movements etc.,), cultures and literatures as a cross-cultural and interdisciplinary study of literature and culture, a new comparative literature. Thanks to comparative literary studies the works are recognized multi-dimensional benefits to self-realization of "self and other" as well as literary qualities and comprehensions of the texts and removing of orientalist and occidentalist misunderstandings, misjudgments or prejudices.

On the other hand, I think the textual analyses of Ellison and Zeyneb Hanım about literary and cultural values of the Orient and the Occident in the light of studies of comparative literature are extremely useful; and they contribute to world literature as comparative cultural studies as well as comparative studies to literature. For example from Fontainebleau, in a letter dated Sept. 1906; Zeyneb Hanım pays attention to comparative impressions of Arabian Nights on her. "When I was quite young I loved to read the history of my country told in the Arabian Nights style. The stories are so vivid and picturesque, that even to-day, I remember the impression my readings made on me” (p. 33).

Of course Harraden's Ships that Pass in the Night as her favorable novel is remembered in one side of her mind as a novel having a remarkable impact on her inner journey. She also takes great aesthetic pleasures from the operas of Vagner. Ellison widely expresses relations and impressions of French, English and Turkish literary works to each other's too. From Nice, in another letter on March 1907, Zeyneb will offer her Western friend, Ellison to visit Turkey. "Go to Turkey and you will see for yourself that everywhere you will be received like a Queen. Everyone will want to be honoured by your presence in their home...” (p. 139).

Having escaped to France, the country of Liberty, Equality, and Fraternity with great expectations, Zeyneb comes face to face with the reality, and she is disappointed. "But now I have seen those three magic words in practice, how the whole course of my ideas has changed! Not only are my theories on the nature of governments no longer the same” (p. 237). Moreover, “she will learn to appreciate her country in the West” (p. 238).

Consequently while Ellison quotes Zeyneb’s ironical approach about dissimilarities of English and Turkish women in the part of introduction of Zeyneb Hanım's work ironical approach; she will take the reader into a colorful comparative journey of these two nations from customs and traditions to cultural life and literary studies of oriental and occidental women for both works as well. "Nothing in our life can be compared to yours, and in a short time you will see this. We have no right to vary ever so little the programme arranged for us by the customs of our country; an adventure of any kind generally ends in disaster. As you may know, we women never see ours (p. xix).

As for Ellison Turkey will be a wonderful experience for her, while leaving Istanbul for her country, "I have spent so many happy days of my life” (p. 211) Ellison expresses her feelings, and she adds "ah! the beautiful unceremoniousness of the East, the absolute sincerity, the liking of one's friends for friendship's sake irrespective of position, and the true brotherhood and democracy of the kindly Turk ... if these qualities must vanish in the inevitable march of progress, then may I never see Turkey again; for, without these qualities, it would no longer be the Turkey I have admired and loved. (p. 201) 


\section{References}

[1] Said, E. (1993) Culture and Imperialism. Alfred A. Knopf, New York, 43.

[2] Tötösy de Zepetnek, S. (1998) Comparative Literature, Theory, Method, Application. Rodopi, Amsterdam-Atlanta, 13.

[3] Said, E. (1993) Culture and Imperialism. Alfred A. Knopf, New York, 45.

[4] Tötösy de Zepetnek, S. (1998) Comparative Literature, Theory, Method, Application. Rodopi, Amsterdam-Atlanta, 30.

[5] Tötösy de Zepetnek, S. (2003) From Comparative Literature Today toward Comparative Cultural Studies. In: Tötösy de Zepetnek, S., Ed., Comparative Literature and Comparative Cultural Studies, Purdue University Press, West Lafayette, 235-262.

[6] Bassnett, S. (1993) Comparative Literature: A Critical Introduction. Blackwell, Oxford, 47.

[7] Spivak, G.C. (2003) Death of a Discipline. Colombia University Press, New York, 26.

[8] Spivak, G.C. (2003) Death of a Discipline. Colombia University Press, New York, 53.

[9] Greene, R. (1995) Their Generation. In: Bernheimer, C., Ed., Comparative Literature in the Age of Multiculturalism, Johns Hopkins UP., Baltimore, London, 144.

[10] Higonnet, M.R. (1994) Introduction. In: Higonnet, M.R., Ed., Borderwork: Feminist Engagements with Comparative Literature, Cornell University Press, Ithaca, 9.

[11] Posnett, H.M. (1886) Comparative Literature. Kegan Paul, Trench, London, VI.

[12] Anzaldia, G. (1987) Borderlands/La Frontera, the New Mestiza. Spinsters/Aunt Lute, San Francisco, 195.

[13] Amoia, A.D. and Knapp, B.L. (2005) Introduction. In: Amoia, A.D. and Knapp, B.L., Eds., Great Women Travel Writers: From 1750 to the Present, A\&C Black, New York, 9-11.

[14] Ellison, G. (1915) An English Woman in a Turkish Harem. Methuen and Co., London, 116.

[15] Lewis, R. (2004) Rethinking Orientalism: Women, Travel and the Ottoman Harem. Rutgers UP., New Brunswick, 135.

[16] Hanum, Z. (1913) A Turkish Woman’s European Impressions. Seeley, Service \& Co., London, 215.

[17] Devy, G. (2002) Translation and Literary History-An Indian View. In: Bassnett, S. and Trivedi, H., Eds., Post-Colonial Translation: Theory and Practice, Routledge, New York, London, 182-189.

[18] Bassnett, S. (1993) Comparative Literature: A Critical Introduction. Blackwell, Oxford, 8-9.

[19] Montagu, M.W. (1906) The Turkish Embassy Letters, 1763. J.M. Dent and Sons, London, 116.

[20] Ternar, Y.Y. (1989) The Book and the Veil: A Critique of Orientalism from a Feminist Perspective. Montréal, Québec, 121.

[21] Lewis, R. (2004) Rethinking Orientalism: Women, Travel and the Ottoman Harem. Rutgers UP., New Brunswick, 222.

[22] Remak, H. (1981) Comparative History of Literatures in European Languages. The Bellagio Report: Neohelicon Acta Comparationis Litterarum Universarum, 8, 221.

[23] Remak, H. (1961) Comparative Literature, Its Definition and Function. In: Stallknecht, N.P. and Frenz, H., Eds., Comparative Literature: Method and Perspective, Southern Illinois University Press, Carbondale, 3. 
Scientific Research Publishing (SCIRP) is one of the largest Open Access journal publishers. It is currently publishing more than 200 open access, online, peer-reviewed journals covering a wide range of academic disciplines. SCIRP serves the worldwide academic communities and contributes to the progress and application of science with its publication.

Other selected journals from SCIRP are listed as below. Submit your manuscript to us via either submit@scirp.org or Online Submission Portal.
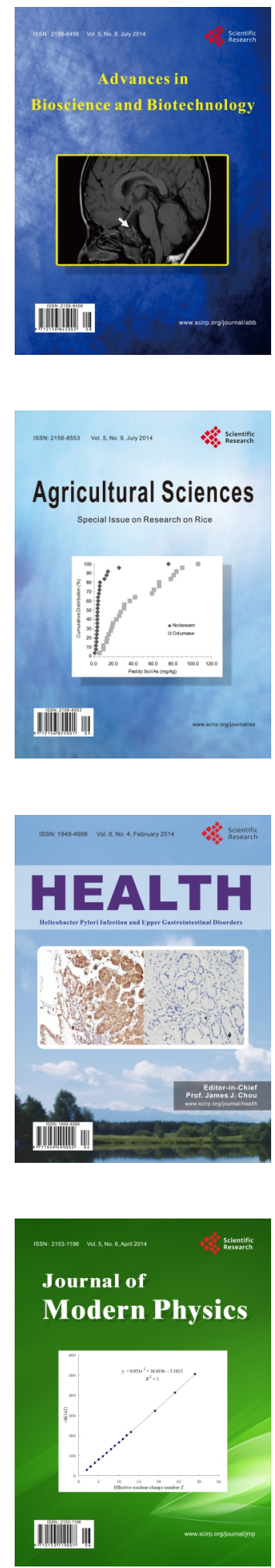
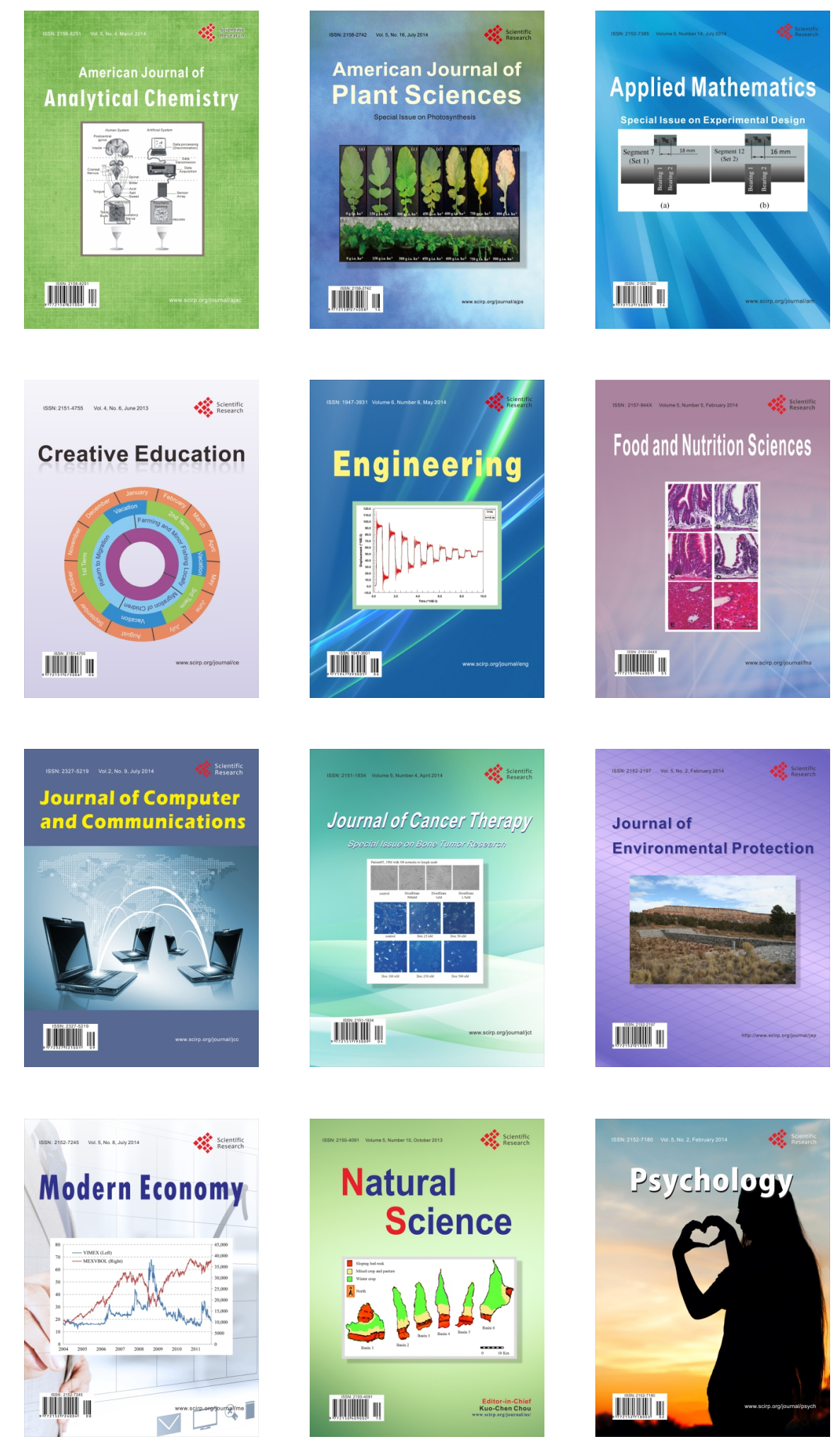